\title{
Pengembangan Aplikasi Pengenalan Aksara Komering Menggunakan Metode Deep Learning Berbasis Android
}

\author{
Mahmud1, Yesi Novaria Kunang*2 \\ ${ }^{1}$ Informatics Departement, Bina Darma University, Palembang, Indonesia \\ 2Information System Departement, Bina Darma University, Palembang, Indonesia \\ Email: myonemahmud@gmail.com ${ }^{1}$, yesinovariakunang@binadarma.ac.id ${ }^{2}$
}

\begin{abstract}
Abstrak
Penggunaan aksara Komering dari waktu ke waktu mulai ditinggalkan di kalangan masyarakat suku Komering dengan banyaknya budaya luar masuk ke Indonesia. Penelitian ini bertujuan untuk melestarikan dan menghidupkan kembali aksara Komering beserta bahasanya dengan menggunakan pemanfaatan teknologi Deep learning yang dibenamkan kedalam aplikasi android. Teknologi DL yang merupakan suatu sub ilmu dari bidang Machine Learning yang dikembangkan atas dasar cara berfikir dari struktur otak manusia sehingga dapat menghasilkan klasifikasi yang lebih baik. Salah satu algoritma dari DL yang terkenal baik dalam mengenali gambar ialah Convolutional Neural Network. Pada penelitian ini percobaan pengklasifikasian gambar aksara Komering dilakukan dengan data sebanyak 1540 gambar, 29 class. Hasil yang didapatkan dari data testing dengan data asli yaitu 58\%, sedangkan untuk testing data augmented $80 \%$. Persentase dalam pengujian aplikasi android melalui kamera $84,14 \%$, galeri $87,58 \%$ dan penulisan $93,79 \%$.
\end{abstract}

Kata Kunci: Aksara Komering, CNN, Deep Learning, Android

\section{PENDAHULUAN}

Aksara Komering merupakan Aksara dari Bahasa Komering yang berasal dari Suku Komering di Kabupaten OKU Provinsi Sumatera Selatan. Aksara ini ialah salah satu aksara turunan dari aksara 'Kaganga' sehingga terdapat beberapa aksara yang memiliki kesamaan, terdiri atas 29 huruf dan terbagi atas 19 konsonan dan 10 vokal dengan awalan 'K'[1]. Dalam penerapannya, Aksara Komering pada era sekarang mulai menurun dikarenakan banyaknya kebudayaan asing yang masuk ke Indonesia. Selain itu minimnya pembelajaran serta pelestarian aksara dari bahasa 
https://journal-computing.org/index.php/journal-cisa/index

daerah sehingga membuat generasi penerus buta akan bahasa dan aksara Komering yang menjadi salah satu bahasa daerah yang ada di Indonesia. Teknologi merupakan suatu alat bukti nyata yang digunakan untuk mempermudah segala aktifitas masyarakat. Pada penelitian ini pemanfaatan teknologi untuk melestarikan bahasa dan aksara Komering dapat dijadikan suatu alat untuk memulai kembali mengingat sekaligus mempelajari kembali bahasa dan aksara Komering yang ada. Adapun teknologi yang akan digunakan pada penelitian ini ialah Deep Learning. Deep learning (DL) merupakan cabang dari Machine Learning yang dapat dikatakan sebagai Neural Network (NN) yang terdiri atas banyak parameter dan layer.

Beberapa Algoritma yang ada pada DL bekerja seperti jaringan syaraf otak manusia yang terdiri atas sebuah neuron atas penambahan fungsi aktifasi, jumlah bobot dan vector masukan. Adapun salah satu implementasi dari teknologi DL terdapat pada algoritma Convolutional Neural Network (CNN)[2]. CNN merupakan salah satu algoritma DL yang hampir sama dengan NN yang tersusun atas neuron dan bias. Berbeda dengan algoritma NN yang hanya fokus bagaimana informasi dari input direpresentasikan melalui banyak fungsi nonlinear, dalam CNN terdapat suatu fungsi yang bernama convolutional layers (CL). CL berfungsi secara khusus untuk mengekstrak gambar menjadi suatu angka berupa array multi-dimensional, dengan menggunakan suatu operasi dot perkalian antara input dan filter yang telah ditetapkan. Dengan adanya proses CL tersebut maka model CNN. akan menghasilkan prediksi yang lebih akurat dan efektif untuk pemrosesan berbentuk gambar dibanding dengan jenis NN lainnya.

Penelitian yang pernah dilakukan yaitu Recognizing Handwritten Japanese Characters Using Deep Convolutional Neural Networks, menggunakan data Electrotechnical Laboratory (ETL) berjumlah jutaan dataset gambar yang terbagi atas 3 tipe yang berbeda diantaranya ialah hiragana, katakana, dan kanji. Dengan pembagian data training sebesar $80 \%$ dan data testing sebesar $20 \%$ didapat dari 3 tulisan tersebut aksara hiragana memiliki akurasi sebesar 96.55\%, aksara katakana memiliki akurasi 98.19\% dan aksara kanji sebesar 99.64\%[3]. Penelitian tersebut berhasil menerapakan model tersebut ke dalam aplikasi android dengan menggunakan library tensorflow. Dengan adanya penggunaan teknologi DL khususnya Algoritma CNN dalam pengklasifikasian suatu gambar, maka dapat diimplemetasikan dengan melihat pengenalan aksara. Penelitian ini nantinya akan berfokus pada 29 aksara komering yang 
nantinya data aksara akan diuji dengan model CNN dengan didapatkannya suatu akurasi dari penelitian ini. Penerapan CNN akan dikembangkan kedalam aplikasi Android yang dimana nantinya pengenalan aksara dapat di deteksi melalui kamera, file gambar, dan penulisan.

\section{METODOLOGI PENELITIAN}

\subsection{Metode Pengumpulan Data}

Pengumpulan data primer dari aksara Komering melalui 50 responden, dimana setiap responden akan menuliskan 29 aksara komering di kertas yang telah disediakan. Selain itu, metode pengumpulan data berasal dari studi literature dari buku maupun jurnal yang berkaitan dengan penelitian yang dilakukan.

\subsection{Pengembangan Model CNN}

Tahapan ini dimulai dari pengumpulan dataset, pelabelan, augmentation hingga proses training model . adapun tahapan-tahapan tersebut ialah sebagai berikut.

1) Tahapan Pengumpulan Dataset Penelitian ini akan mengumpulkan dataset dari responden sebanyak 50 orang, responden nantinya akan menulis 29 aksara komering dari lembar yang telah disediakan.

2) Pelabelan Dataset Setelah mendapatkan data dari responden, pelabelan dari setiap aksara yang sudah digenerate. Pada proses ini dilakukan dengan cara crop setiap bagian aksara menjadi bagianbagian kecil yang terpisah. Selain pelabelan dalam tahapan ini melakukan pembagian antara dataset untuk proses training dan testing.

3) Data Augmentation Proses Data augmentation dilakukan untuk memperbanyak dataset dengan melakukan proses rotation, translation, contrass dan saturation terhadap dataset.

4) Data Prepocesing Tahapan ini berfungsi untuk melakukan pengecekan posisi, resize, grayscale terhadap dataset baik training maupun testing.

5) Training Model Tahapan dimana pengembangan model atau bisa di sebut dengan proses training model.

6) Pengujian model Tahapan pengujian model memiliki tujuan untuk melihat akurasi dari model yang telah di kembangkan. Dengan 
https://journal-computing.org/index.php/journal-cisa/index

melakukan pengujian model, maka akan diketahui apakah suatu model dapat diimplementasikan ke dalam aplikasi.

\subsection{Implementasi CNN Android}

Setelah melakukan pengembangan model CNN yang dimana pengujian dilakukan dengan mengikuti tahapan-tahapan yang ada, akan dilanjutkan pengembangan Aplikasi dengan mengimplementasikan CNN kedalam Android sekaligus pengujian tingkat akurasi pada aplikasi tersebut.

1) Konversi Model Proses ini dilakukan agar model dapat digunakan dalam pemrograman berbasis javascript. Hal tersebut dilakukan karena proses training model dilakukan dengan bahasa python sedangkan server side dibuat dengan menggunakan bahasa javascript sehingga diperlukan konversi model.

2) Pengembangan dan pengujian Aplikasi pengembangan aplikasi android serta aplikasi server (rest api) yang berguna untuk menghubungkan aplikasi dengan model yang berada dilingkungan server. Pengujian dilakukan ketika model sudah diimplementasikan kedalam aplikasi. Aplikasi akan dilakukan pengujian untuk mengklasifikasikan data baru dari beberapa Aksara Komering.

\section{HASIL DAN PEMBAHASAN}

\subsection{Pengumpulan Dataset}

Pengumpulan dataset dari aksara Komering dilakukan oleh 50 responden dengan melakukan generate aksara Komering secara menulisnya ke dalam 1 lembar kertas bertabel. Dari hasil generate aksara tersebut, peneliti mendapatkan 50 kertas yang berisi aksara sebanyak 1450 gambar yang terbagi atas 29 aksara Komering. Berikut sampel gambar dari pengumpulan dataset dapat dilihat pada Gambar 1.

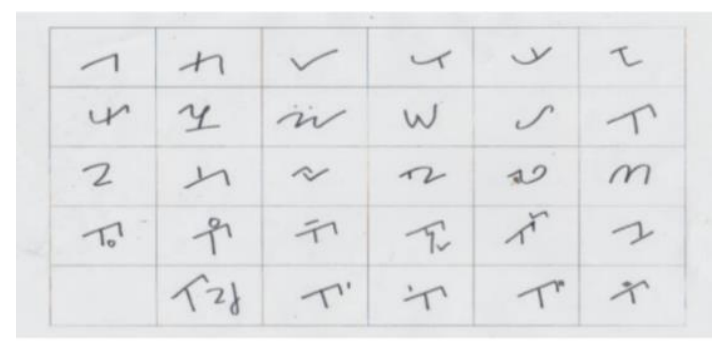

Gambar 1. Sampel Data Responden 
Vol. 1, No. 2, May 2020 e-ISSN: 2775-2496

https://journal-computing.org/index.php/journal-cisa/index

\subsection{Pelabelan Dataset}

Tahapan pelabelan dari setiap gambar aksara yang sudah digenerate. Proses croping dilakkuan satu persatu dari setiap bagian sehingga menjadi bagian bagian kecil yang terpisah. Berikut gambar 2. Pemisahan aksara komering.

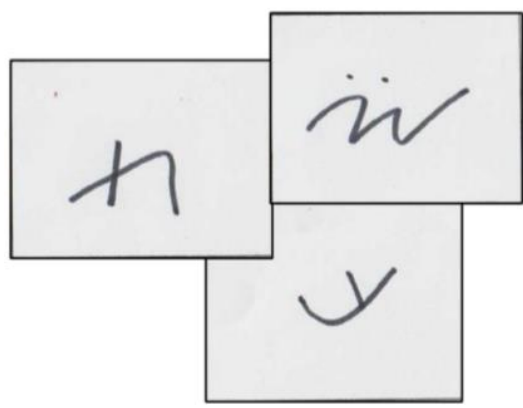

Gambar 2. Pemisahan Aksara

Setelah proses croping selesai, proses selanjutnya ialah proses pelabelan dataset. Proses pelabelan ini dilakukan secara manual dengan mengelompokan aksara yang sama kedalam suatu folder yang mana penamaan dari folder tersebut didapat dari nama ejaan dari suatu aksara yang akan dikelompokkan. Dapat dilihat pada Gambar 3.

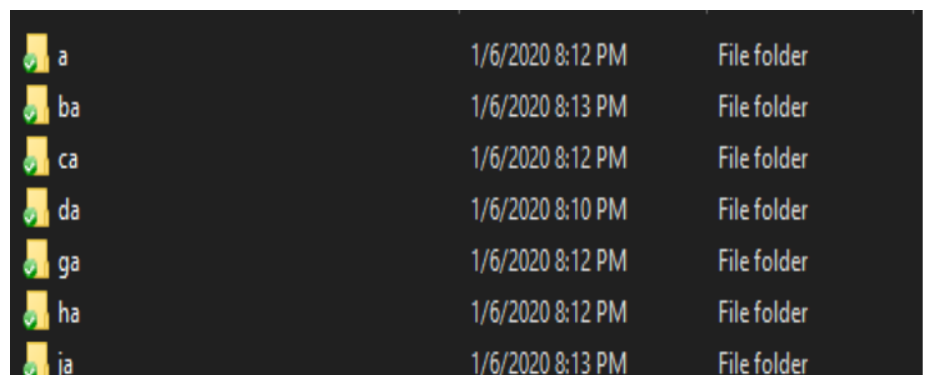

Gambar 3. Pelabelan aksara Komering

\subsection{Build Model Proses}

Pengembangan model ini dilakukan dengan menggunakan keras yang ditenagai oleh library Tensorflow backend. Dengan menggunakan dataset asli serta dataset yang dilakukan proses augmented, penulis melakukan proses training yang dilakukan dengan menggunakan epoch sebanyak 120 dan 36 batch size. jika data training berjumlah 1044 maka dalam 
Vol. 1, No. 2, May 2020 e-ISSN: 2775-2496

https://journal-computing.org/index.php/journal-cisa/index

setiap putaran epoch akan terdiri atas 29 gambar aksara yang akan diproses kedalam convolution. Adapun tabel arsitektur dapat dalam pembuatan model dapat dilihat pada tabel 1 .

Tabel 1 Arsitektur dan jumlah parameter layer

\begin{tabular}{|c|c|c|}
\hline Layer & Output shape & $\begin{array}{l}\text { Number of } \\
\text { parameter }\end{array}$ \\
\hline $\operatorname{conv2d}($ Conv2D) & (None, 64, 64, 64) & 640 \\
\hline batch_normalization & (None, 64, 64, 64) & 256 \\
\hline activation (Activation) & (None, 64, 64, 64) & 0 \\
\hline max_pooling $2 d$ & (None, 32, 32, 64) & 0 \\
\hline dropout (Dropout) & (None, 32, 32, 64) & 0 \\
\hline $\operatorname{conv} 2 d \_1($ Conv2D) & (None, 32, 32, 128) & 73856 \\
\hline max_pooling2d_1 & (None, 16, 16, 128) & 0 \\
\hline activation_l(Activation) & (None, 16, 16, 128) & 0 \\
\hline dropout_1 (Dropout) & (None, 16, 16, 128) & 0 \\
\hline conv2d_2(Conv2D) & (None, 16, 16, 256) & 295168 \\
\hline max_pooling2d_2 & (None, 8, 8, 256) & 0 \\
\hline activation_2 (Activation) & (None, 8, 8, 256) & 0 \\
\hline dropout_2 (Dropout & (None, 8, 8, 256) & 0 \\
\hline $\operatorname{conv} 2 d \_3(\operatorname{Conv} 2 D)$ & (None, 8, 8, 256) & 590080 \\
\hline max_pooling2d_3 & (None, 4, 4, 256) & 0 \\
\hline activation_3 (Activation) & (None, 4, 4, 256) & 0 \\
\hline dropout_3 (Dropout) & (None, 4, 4, 256) & 0 \\
\hline flatten (Flatten) & (None, 4096) & 0 \\
\hline dense (Dense) & (None, 512) & 2097664 \\
\hline activation_4 (Activation) & (None, 512) & 0 \\
\hline dropout_4 (Dropout) & (None, 512) & 0 \\
\hline dense_l(Dense) & (None, 256) & 131328 \\
\hline activation_5 (Activation) & (None, 256) & 0 \\
\hline dropout_5 (Dropout) & (None, 256) & 0 \\
\hline dense_2 (Dense) & 29 & 7453 \\
\hline
\end{tabular}

\subsection{Hasil Pengujian Model}

Proses pengujian model memiliki tujuan utama untuk melihat apakah model dapat mengenali aksara Komering dengan baik atau tidak. Proses pengujian terhadap model dilakukan dengan menggunakan library sklearn terhadap data asli maupun dataset asli yang sudah dilakukan proses augemented. Bentuk pengujian model yang dilakukan peneliti yaitu mengetahui nilai confusion matrix dari hasil prediksi data testing 
Vol. 1, No. 2, May 2020 e-ISSN: 2775-2496

https://journal-computing.org/index.php/journal-cisa/index

sebagai nilai awal untuk menentukan besaran akurasi testing, nilai precision, recall hingga f1-score.

\subsubsection{Hasil Testing Data Asli}

Pengujian model menggunakan dataset asli dilakukan dengan jumlah dataset testing sebanyak 5 gambar aksara. Kelima gambar aksara tersebut merupakan data testing yang mewakili setiap aksara, sehingga jumlah keseluruhan data testing ialah sebanyak 145 (29x5) gambar aksara. Adapun hasil pengujian dari data testing yang dilakukan dapat dilihat pada gambar 4 confusion matrix.

\section{Confusion Matrix}

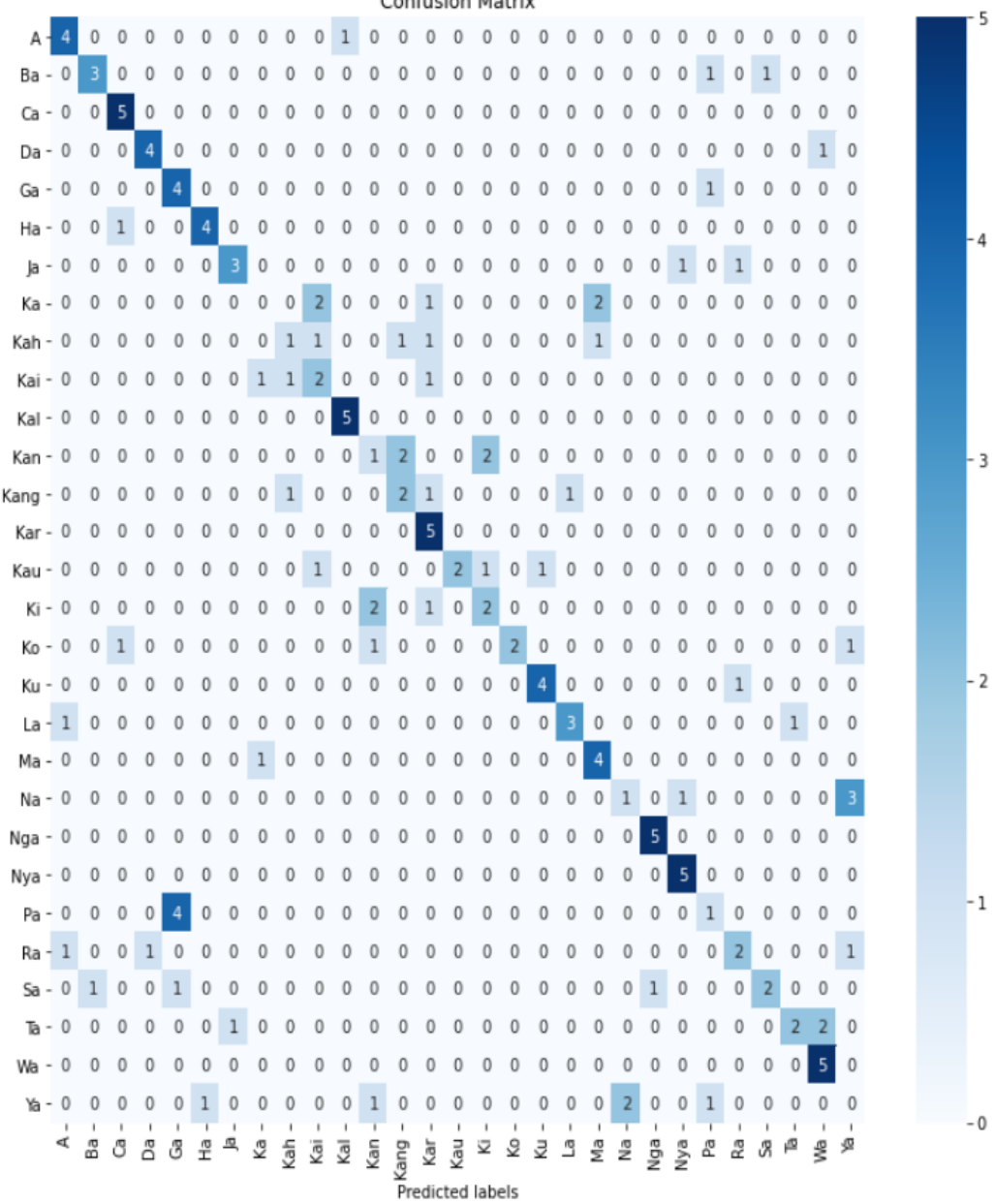

Gambar 4. Confussion Matrix Data Asli 
Vol. 1, No. 2, May 2020 e-ISSN: 2775-2496

https://journal-computing.org/index.php/journal-cisa/index

Peneliti membagi 3 kelompok aksara berdasarkan hasil nilai pengujian dataset testing. Ketiga kelompok digunakan untuk mengelompokkan aksara-aksara dari data testing yang diklasifikasikan dengan nilai sangat baik yaitu jumlah TP 4 sampai 5, baik dengan jumlah TP 3, sedangkan kurang baik dengan jumlah TP 0 hingga 2 . Proses pengelompokan aksara dilakukan dengan menyeleksi dari besaran jumlah TP yang didapat pada confusion matriks. Adapun gambar dari confusion report yang meliputi precision, recall, f1-score dari setiap aksara yang dilakukan pengujian dengan menggunakan dataset asli dapat dilihat pada gambar 5 .

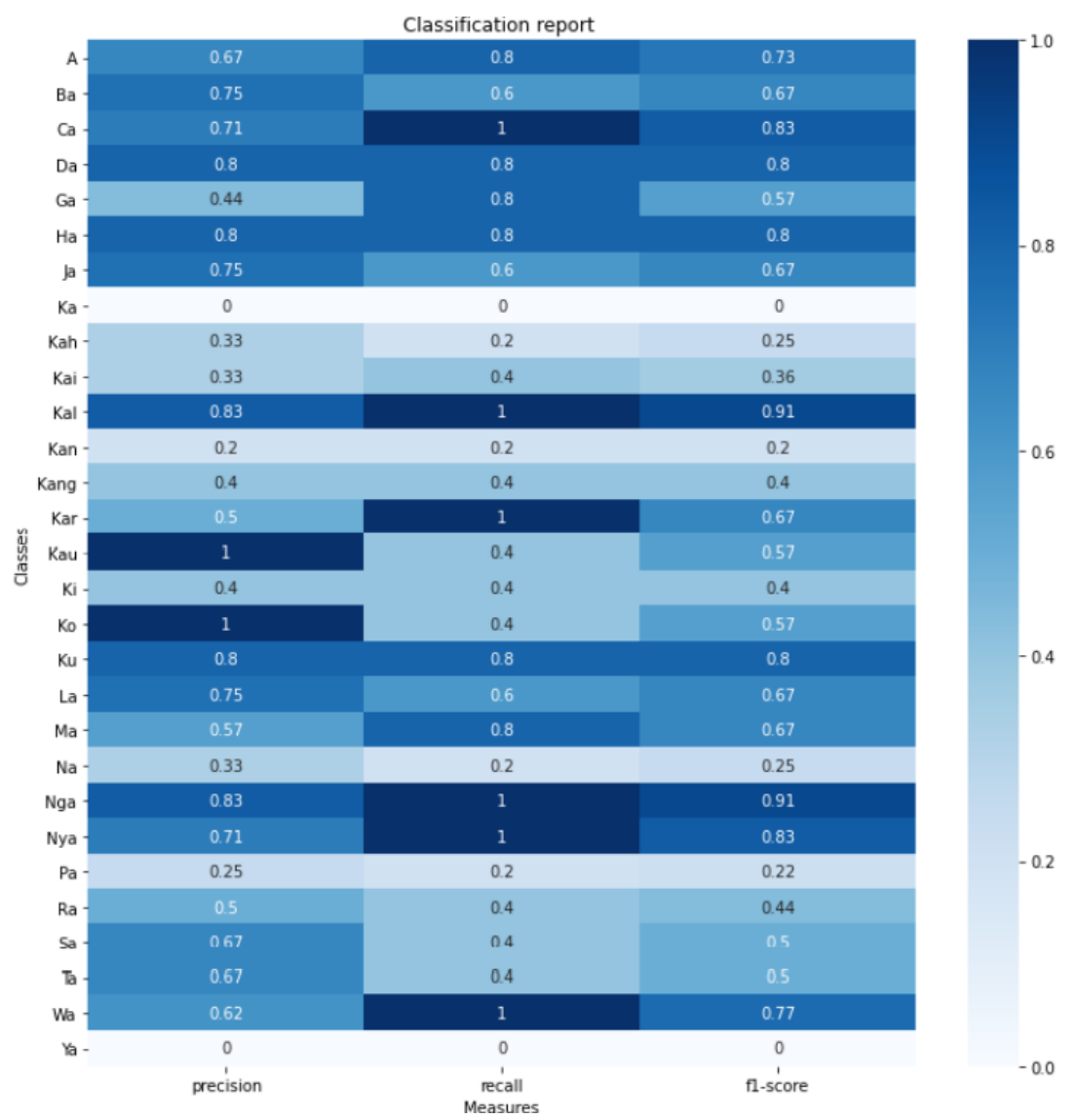

Gambar 5. Classification Report Data Testing Asli

Hasil keseluruhan yang didapati penulis dalam pengujian dengan menggunakan data asli, nilai rata-rata pada precision ialah sebanyak $57 \%$, sedangkan rata-rata recall sebanyak 57\%, dan f1-score dengan rata-rata $55 \%$. 
Vol. 1, No. 2, May 2020 e-ISSN: 2775-2496

https://journal-computing.org/index.php/journal-cisa/index

\subsubsection{Hasil Testing Data Augmented}

Pengujian ini dilakukan dengan data asli yang telah dilakukan proses augmented. Dari proses augmented tersebut menghasilkan dataset baru yang digunakan untuk testing \pm 96 dalam setiap aksara atau \pm 2765 secara keseluruhan. Dari hasil pengujian model yang dilakukan dengan menggunakan dataset yang telah dilakukan proses augmented, peneliti mendapatkan hasil confusion matrix yang dapat dilihat pada gambar 6 .

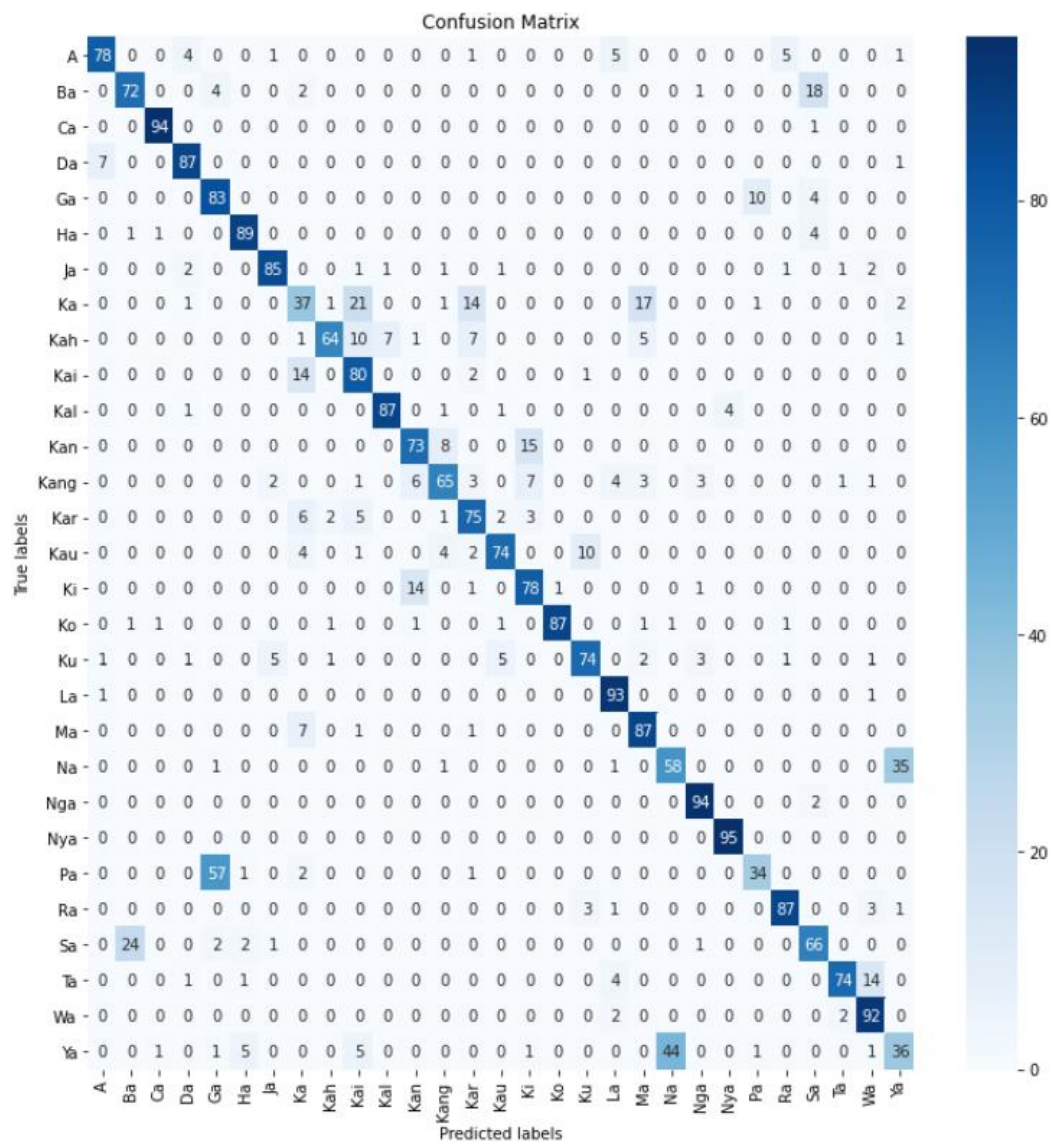

Gambar 6. Confussion Matrix Data Augmented

Dalam Confusion matrix Data Augmented juga dibagi menjadi 3 pengelompokan, dimana Jumlah TP yang melebihi nilai 80 dikatakan sangat baik, untuk jumlah TP 60-79 dikatakan baik, sedangkan jumlah TP dibawah 60 dapat dikatakan kurang baik. Adapun untuk Classification Report dapat dilihat pada gambar 7. 


\section{Journal of Computer and Information Systems Ampera}

Vol. 1, No. 2, May 2020 e-ISSN: 2775-2496

https://journal-computing.org/index.php/journal-cisa/index

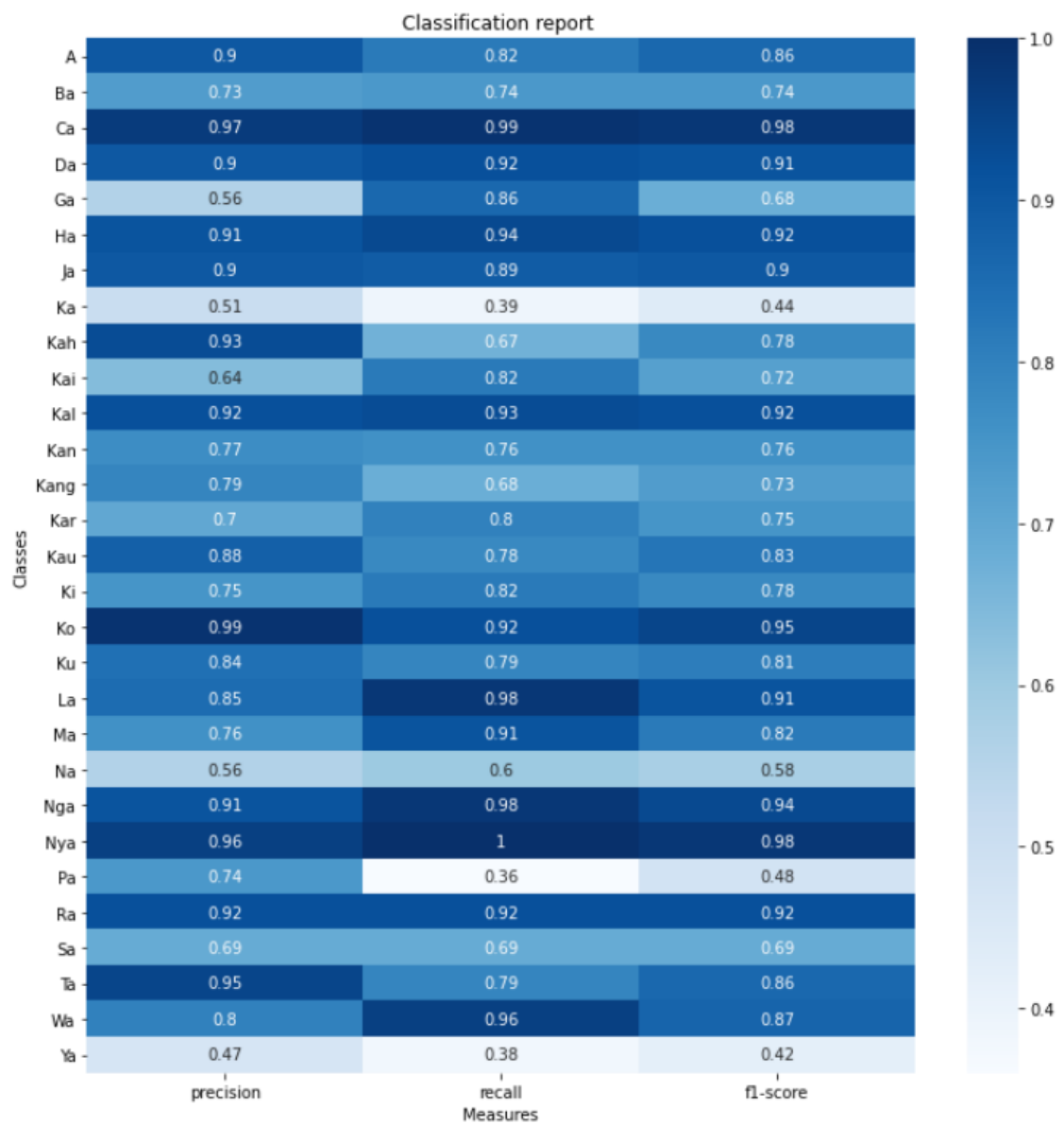

Gambar 7. Classification Report Augmented

Hasil pengujian yang didapati dengan menggunakan data augmented, nilai rata-rata precision ialah sebesar $80 \%$ dengan rata-rata recall sebesar 79\%, dan f1-score sebesar 79\%. Jika dibandingkan dengan pengujian data asli, persentase yang didapatkan pada pengujian data augmented lebih tinggi.

\subsection{Hasil Pengujian Aplikasi}

Dalam implementasi pengujian di aplikasi dapat melalui dengan 3 cara yaitu kamera, galeri gambar, dan ditulis. Berikut gambar-gambar aplikasi yang dapat dilihat pada gambar 8-9. 
Journal of Computer and Information Systems Ampera

Vol. 1, No. 2, May 2020 e-ISSN: 2775-2496

https://journal-computing.org/index.php/journal-cisa/index

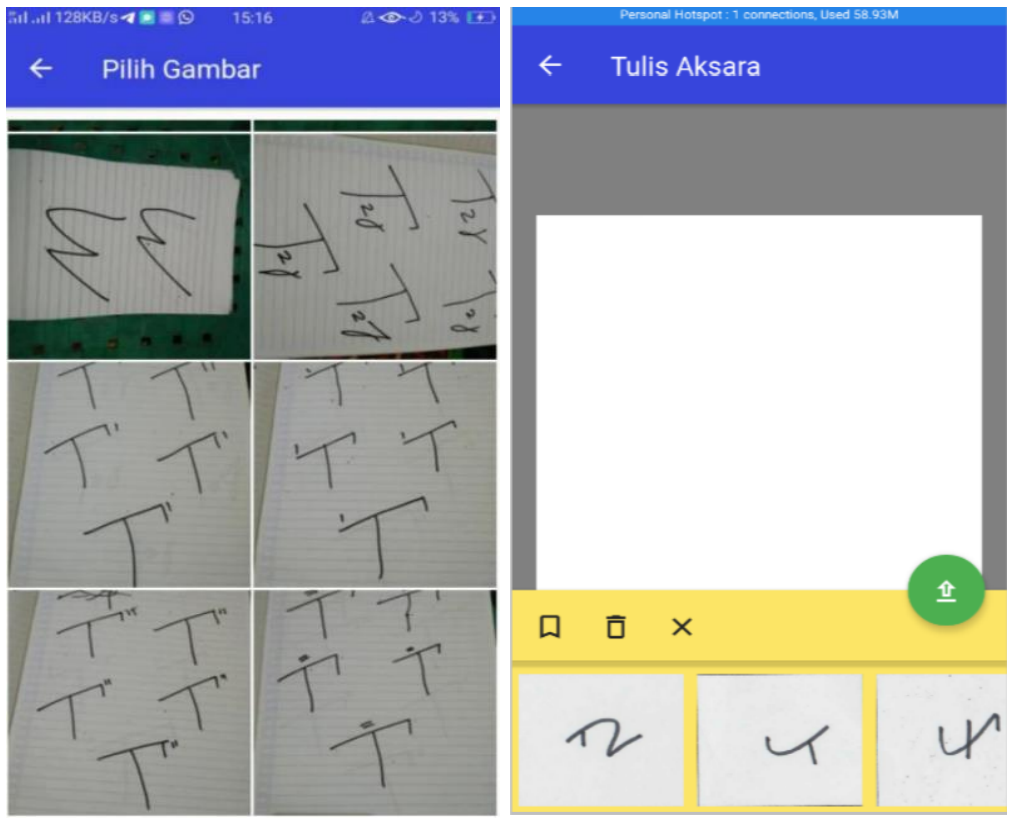

Gambar 8. Gambar klasifikasikan dan Aksara Komering

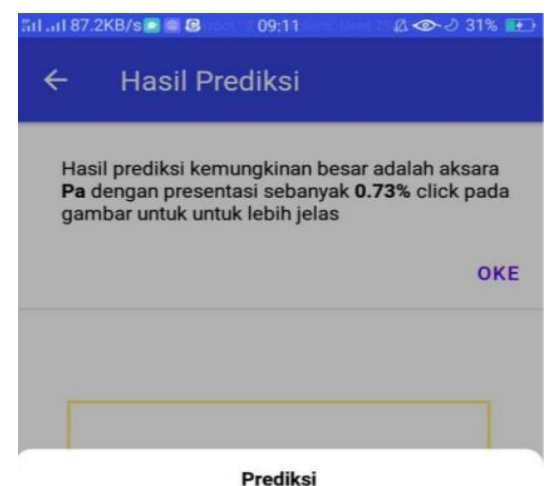

Prediksi aksara

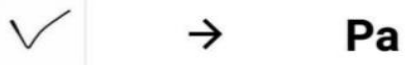

$0.73 \%$ akurasi

Apakah prediksi ini benar?

Tidak Benar

Gambar 9. Hasil klasifikasi aksara 
Adapun hasil pengujian dari aplikasi dengan 5 kali percobaan melalui kamera, galeri, dan penulisan dapat dilihat pada tabel 2 .

Tabel 2. Pengujian Melalui Aplikasi

\begin{tabular}{|c|c|c|c|c|c|c|c|c|}
\hline \multirow{2}{*}{\multicolumn{2}{|c|}{$\begin{array}{l}\text { a } \\
\text { r } \\
\text { j }\end{array}$}} & \multirow[t]{2}{*}{ Aksara } & \multicolumn{3}{|c|}{ Jumlah sampel percobaan } & \multicolumn{3}{|c|}{$\begin{array}{l}\text { Jumlah aksara terklasifikasi } \\
\text { (benar|salah) }\end{array}$} \\
\hline & & & Kamera & Gallery & signature & Kamera & Gallery & signature \\
\hline & 1 & A & 5 & 5 & 5 & $4 \mid 1$ & $4 \mid 1$ & $5 \mid 0$ \\
\hline $\mathrm{t}$ & 2 & $\mathrm{Ba}$ & 5 & 5 & 5 & $5 \mid 0$ & $5 \mid 0$ & $5 \mid 0$ \\
\hline $\begin{array}{l}\mathrm{a} \\
\mathrm{b}\end{array}$ & 3 & $\mathrm{Ca}$ & 5 & 5 & 5 & $5 \mid 0$ & $5 \mid 0$ & $5 \mid 0$ \\
\hline e 4 & 4 & $\mathrm{Da}$ & 5 & 5 & 5 & $5 \mid 0$ & $5 \mid 0$ & $4 \mid 1$ \\
\hline 15 & 5 & $\mathrm{Ha}$ & 5 & 5 & 5 & $5 \mid 0$ & $5 \mid 0$ & $5 \mid 0$ \\
\hline $\mathrm{p}$ & 6 & $\mathrm{Ja}$ & 5 & 5 & 5 & $2 \mid 3$ & $2 \mid 3$ & $3 \mid 2$ \\
\hline e & 7 & $\mathrm{Ka}$ & 5 & 5 & 5 & $5 \mid 0$ & $5 \mid 0$ & $5 \mid 0$ \\
\hline $\begin{array}{l}\mathrm{n} \\
\mathrm{g}\end{array}$ & 8 & Kah & 5 & 5 & 5 & $4 \mid 1$ & $4 \mid 1$ & $5 \mid 0$ \\
\hline u & 9 & Kai & 5 & 5 & 5 & $5 \mid 0$ & $5 \mid 0$ & $5 \mid 0$ \\
\hline & 10 & Kal & 5 & 5 & 5 & $5 \mid 0$ & $5 \mid 0$ & $5 \mid 0$ \\
\hline a 1 & 11 & Kan & 5 & 5 & 5 & $3 \mid 2$ & $3 \mid 2$ & $5 \mid 0$ \\
\hline $\mathrm{n}_{1}$ & 12 & Kang & 5 & 5 & 5 & $5 \mid 0$ & $5 \mid 0$ & $5 \mid 0$ \\
\hline $\mathrm{d}^{1}$ & 13 & Kar & 5 & 5 & 5 & $3 \mid 2$ & $3 \mid 2$ & $4 \mid 1$ \\
\hline $\begin{array}{ll}\text { i } & 1\end{array}$ & 14 & $\mathrm{Kau}$ & 5 & 5 & 5 & $5 \mid 0$ & $5 \mid 0$ & $5 \mid 0$ \\
\hline $\begin{array}{ll}a & 1\end{array}$ & 15 & $\mathrm{Ki}$ & 5 & 5 & 5 & $5 \mid 0$ & $5 \mid 0$ & $3 \mid 2$ \\
\hline a 1 & 16 & Ko & 5 & 5 & 5 & $5 \mid 0$ & $5 \mid 0$ & $5 \mid 0$ \\
\hline $\begin{array}{ll} & 1\end{array}$ & 17 & $\mathrm{Ku}$ & 5 & 5 & 5 & $3 \mid 2$ & $3 \mid 2$ & $5 \mid 0$ \\
\hline 1 & 18 & $\mathrm{La}$ & 5 & 5 & 5 & $3 \mid 2$ & $3 \mid 2$ & $5 \mid 0$ \\
\hline p 1 & 19 & $\mathrm{Ma}$ & 5 & 5 & 5 & $4 \mid 1$ & $4 \mid 1$ & $5 \mid 0$ \\
\hline $\begin{array}{l}e^{e} \\
\mathrm{r}\end{array}$ & 20 & $\mathrm{Na}$ & 5 & 5 & 5 & $5 \mid 0$ & $5 \mid 0$ & $5 \mid 0$ \\
\hline s 2 & 21 & Nga & 5 & 5 & 5 & $5 \mid 0$ & $5 \mid 0$ & $4 \mid 1$ \\
\hline $\begin{array}{ll}e & 2 \\
n\end{array}$ & 22 & Nya & 5 & 5 & 5 & $4 \mid 1$ & $4 \mid 1$ & $5 \mid 0$ \\
\hline${ }_{t}^{n} 2$ & 23 & $\mathrm{~Pa}$ & 5 & 5 & 5 & $4 \mid 1$ & $4 \mid 1$ & $5 \mid 0$ \\
\hline a 2 & 24 & $\mathrm{Ra}$ & 5 & 5 & 5 & $5 \mid 0$ & $5 \mid 0$ & $5 \mid 0$ \\
\hline $\begin{array}{l}\mathrm{s} \\
\mathrm{e}\end{array}$ & 25 & $\mathrm{Sa}$ & 5 & 5 & 5 & $3 \mid 2$ & $3 \mid 2$ & $5 \mid 0$ \\
\hline & 26 & $\mathrm{Ta}$ & 5 & 5 & 5 & $4 \mid 1$ & $4 \mid 1$ & $3 \mid 2$ \\
\hline y 2 & 27 & Wa & 5 & 5 & 5 & $5 \mid 0$ & $5 \mid 0$ & $5 \mid 0$ \\
\hline${ }_{n}^{2} 2$ & 28 & $\mathrm{Ya}$ & 5 & 5 & 5 & $5 \mid 0$ & $5 \mid 0$ & $5 \mid 0$ \\
\hline g 2 & 29 & $\mathrm{Ga}$ & 5 & 5 & 5 & $3 \mid 2$ & $3 \mid 2$ & $5 \mid 0$ \\
\hline
\end{tabular}


https://journal-computing.org/index.php/journal-cisa/index

Dari tabel diatas didapatkan yaitu $84,14 \%$ dari seluruh pengujian yang dilakukan dengan menggunakan kamera dapat diklasifikasikan dengan benar, sedangkan 15,86\% diklasifikasikan dengan salah. Adapun pengujian yang dilakukan dengan menggunakan galery, persentase melebihi persentase yang dilakukan dengan kamera dimana jumlah benar dari pengujian ini mencapai $87,58 \%$ sedangkan aksara diklasifikasikan dengan salah sebanyak $12,41 \%$. Dan untuk hasil dari proses pengujian aksara dengan menulis secara langsung kedalam aplikasi yaitu sebanyak 93,79\% gambar dapat diklasfiikasikan dengan benar dan 6,21\% aksara kenali dengan salah.

\section{KESIMPULAN}

Kesimpulan dari penelitian yang dilakukan dalam pengenalan aksara Komering dengan menggunakan metode DL algoritma CNN yaitu 2. Tingkat akurasi testing dari proses training model dengan menggunakan data augmented jauh lebih baik dibanding tingkat akurasi dengan menggunakan data asli. Akurasi testing dari training data asli didapat sebanyak 57\%, sedangkan akurasi testing dengan data augmented sebanyak $80 \%$. Adapun pada implementasi aplikasi data yang digunakan sebanyak 5 hampir mendapatkan akurasi yang bervariasi dengan persentase penggunaan kamera $84,14 \%$, galeri $87,58 \%$ dan penulisan $93,79 \%$.

\section{DAFTAR PUSTAKA}

[1] H.M. Hatta Ismail, \& H.M. Arlan Ismail. (2002). ADAT PERKAWINAN KOMERING ULU SUMATERA SELATAN (1st ed.). Unanti Press Palembang.

[2] Josh Patterson and Adam Gibson. (2017). Deep Learning A Practitioner's Approach (1st ed.). O'Reilly Media, Inc., 1005 Gravenstein Highway North, Sebastopol, CA 95472. http://oreilly.com/catalog/errata.csp?isbn $=9781491914250$

[3] Charlie Tsai. (2016). Recognizing Handwritten Japanese Characters Using Deep Convolutional Neural Networks. 1-7.

[4] Monden, Y., 1993. Toyota Production System: An Integrated Approach to Just-in-Time, 2nd ed., Industrial Engineering and Management Press, Norcross, GA. 